\title{
CAN THE RIGHT TO EDUCATION BE SUCCESSFULLY IMPLEMENTED THROUGH NEW TECHNOLOGIES?
}

\author{
M.M. Magalhães Silva1 ${ }^{1}$ D.R. Alves ${ }^{1}$, M.J. Ferreira ${ }^{2,3}$ \\ ${ }^{1}$ Univ Portucalense, Portucalense Institute for Legal Research - IJP (PORTUGAL) \\ ${ }^{2}$ Univ Portucalense, Research on Economics, Management and Information Technologies - \\ REMIT (PORTUGAL) \\ ${ }^{3}$ Centro Algoritmi, Universidade do Minho (PORTUGAL)
}

\begin{abstract}
The right to education emerges as a fundamental right and instrument of democracy that has accompanied the evolution of the social and democratic state of Western and European law. And can the right to education be successfully implemented through new technologies?

It is possible to find the right to education legally enshrined either in the domestic law of states, in constitutional texts, in international law or in general organizations such as the United Nations (UN) or regional organizations such as the European Union (EU). In this context, information technologies emerge as a tool that, given their ubiquity and unquestionable use by all generations and those at present in the school age, can and should be used to increase this right with success. In the specific national case of the Constitution of the Portuguese Republic of 1976, the right to education is presented as a freedom and as a cultural right. At international law, the right to education emerges as one of the goals of the UN and is enshrined in the European Union. Also, to note that this right, as a second generation social right, depends on public policies and financial endowment.
\end{abstract}

The right to education, as well as the right to vocational and continuing training - long life education - is valued by the European Union, which shapes the orientation of the Member States in their performance. The right to education as a fundamental right is itself a vehicle for the consecration of fundamental rights as a whole. The development of a policy of raising awareness and educating the public on fundamental rights by states and international organizations that have a practice in this area allows for great achievements in the field of fundamental rights. The education system, possibly through the use of new technologies (ICTs), will be responsible for maintaining the skills (knowledge, skills and attitudes) given the profile of today's students, essential to the pursuit of democratic ideals.

The aim is here to discuss the extent to which these new technologies can ensure a more effective implementation of constitutionally established law. The value of the rule of law remains a priority today. But we can see that the realization of the right to education is not yet fully realized. And it will be also through the politics of education and training that the common values and the general principles of law will be maintained. The focus of state and international community intervention was also a necessity and priority.

This study intends to focus on the legislative documents and case studies presented in the literature that address the issue of valuing the use of new technologies in the realization of this right. On a theoretical and academic view, it is consolidated through the systematic and methodologically selected normative interpretation of the legislative texts. Without presenting quantitative data, the aim is to bring to discussion and debate the role, value and capacity of the use of new technologies in enforcing a positive right that depends on the State's action to achieve it. The analysis of the progress historically achieved towards the consolidation of the right to education leads to the recommendation to the states, both internally and as members of international organizations, to value education as a vehicle for the realization of democratic values. To this end, the role of new technologies will be paramount if and to the extent that public policies value and promote it.

Keywords: New technologies, Right to education, European Union.

\section{INTRODUCTION}

The right to education emerges as a fundamental right and an instrument of democracy that has followed the evolution of the social and democratic state of Western and European Law. 
It is possible to find the right of education legally enshrined both in the states' domestic law, in constitutional texts, both in international law and general organizations such as the United Nations (UN) or regional organizations such as the European Union (EU). In the specific case of the Constitution of the Portuguese Republic of 1976, the right of education is presented as a freedom and as a cultural right, inserted in the economic, cultural and social rights. In international law, the right of education emerges as one of the objectives of UN's 2030 Agenda and it is consecrated in the European Union's texts of the institutional treaties as well as in the Charter of Fundamental Rights of the European Union.

Within the UN, the 17 Sustainable Development Objectives with 169 goals adopted in 2015 demonstrate the scale of this universal Agenda to be achieved by 2030. Objective 4 comes to "ensure inclusive, equitable and quality education, as well as to promote lifelong learning opportunities for all". Not forgetting that the right of education arises as a second-generation social right [1], this will make its implementation dependant on public policies and financial allocation.

The right to education, as well as the right to vocational and continuing training - long life education are worthy of attention in recent European Union documents which, without the dignity of legislative acts, slowly shape the Member States' orientation in their performance.

The right to education as a fundamental right is itself a vessel for the enshrinement of fundamental rights as a whole. The development of awareness and education policies of citizens by the State and International Organizations in matter of fundamental rights will allow great achievements.

The rule of law remains today as a priority. However, the implementation of the right to education is not yet achieved in its fullness. And it will also be through education and training policies that common values and general principles of law will be maintained. The focus of intervention by the State and the international community is still a necessity and a priority.

The historical analysis of the progress achieved in the consolidation of the right of education has led to recommendation to States, either internally or as members of international organizations, who value education as a vehicle for achieving democratic values.

\section{THE PLACEMENT OF THE RIGHT TO EDUCATION}

The right to education as a fundamental right arose already in the phase of the Constitutional State and as a key element in a functioning democratic system. Moreover, education represents today an economic and development [12] value, with knowledge at the heart of the European Union's efforts to achieve smart, sustainable and inclusive [15] growth.

The constitutional objectives of education are congruent with a democratic and social rule of law to form free civically active, supportive and responsible [28] citizens.

Similarly, modern and effective higher education systems will be the foundations of an open, confident and sustainable society, and a creative, innovative, entrepreneurial and knowledge-based economy [20]. Joint efforts by the authorities of the Member States, higher education institutions, stakeholders and the European Union will be crucial in achieving Europe's most successful objectives [15].

Furthermore, education plays a key role in learning and exercise of human rights [9], never definitively guaranteed, bur in a permanent and urgent construction. In this context/framework, universities are vital actors for Europe's future [25] and for the successful transition for a knowledge-based economy and society. However, this crucial sector of the economy and society still lacks restructuring and modernization, indispensable conditions for Europe to win the global competition in education, research and innovation [17] [11].

\section{THE RIGHT TO EDUCATION IN THE PORTUGUESE CONSTITUTION}

In Portuguese constitutional law, it is with the end of the absolute state in 1820 [35] that all Constitutions consecrate the right of education as a fundamental right: Constitution of 1822, in articles 237 to 239; Constitutional Charter of 1826, article 145, $\S 30$ e $\S 32$; Constitution of 1838, articles 28 and 29; Constitution of 1911, article 3, paragraphs 10 and 11; and Constitution of 1933, articles 42 and 43 [30]. 
Today, in the Constitution of the Portuguese Republic (CRP) of $2^{\text {nd }}$ of April of 1976, the right to education is contemned, as freedom, in Article 43: "1. The freedom to learn and to teach is guaranteed. 2. The State cannot program education according to any philosophical, aesthetic, political, ideological or religious guidelines. 3. Public education shall not be confessional. (...)" however, since education is a special expression of culture, it is also a cultural right inserted in economic, social and cultural rights in Chapter III of Title III of Part I, Articles 73 to 77.

On a positive side, as a typical social security right, it involves necessarily the intervention of the State or States to enforce it as a right of access to the school, as a right to obtain education, which represents an obligation of the State [8] to create and to maintain schools [28], being also possible to find in it a negative strand of freedom [2]. It should be noted that this right to education, a right of personal nature is addressed to national citizens and foreigners (under Article 15 of the CRP), which falls within the European Union's current concerns, as we will see further ahead [4].

\section{THE RIGHT TO EDUCATION IN THE EUROPEAN UNION}

In the texts of international law, although absent from the initial text of the European Convention on Human Rights of 1950 (The European Convention on Human Rights or the European Convention for the Protection of Human Rights and Fundamental Freedoms was signed in Rome on November 4 1950 as part of the Council of Europe's main task of safeguarding human rights. The Convention entered into force on 3 September 1953. Portugal ratified it by Law no. 65/78 of October 13 in the Official Journal no. 236, I Série, pp. 2119 to 2145), the right to education appears in an additional protocol to the same document, article 2. In the previous Universal Declaration of Human Rights of 1948, it resulted in article 26 (On December 10, 1948, the United Nations General Assembly approves in Paris, with 48 countries, resolution 217a (III) with the text of 30 articles of the Universal Declaration of Human Rights. Subscribed by more than 180 countries up to this day, Portugal joined on December 141955 and published it in the Official Journal, I Series A, N. ${ }^{\circ} 57 / 78$ of 9 March.). In the European Union, education as a policy arises in Article 165 of the Treaty on the Functioning of the European Union [34]. The right to education today arises in the Charter of Fundamental Rights of the European Union since the 2000 [21] version and now in 2007 [26] in article 14.

Without a definition of what the legal text understands by education, as it happens in Portuguese fundamental law, it is certain that inclusiveness is today a fundamental concept in this subject [5], attentive to globalization, incentives to freedom of movement according to the construction of the internal market and the most recent concerns about the need for Member States to make their education systems more adequate, with particular regard to the integration of refugees and migrants.

This is the issue of accessibility, which is therefore relevant for migrant and displaced populations, refugees and ethnic minorities [5]. The linguistic question is also relevant. It is worth mentioning that appreciation of this strand functions as a characteristic that identifies the European Union in the world of international organizations and can be found in the institutive treaties themselves, in text of secondary law, in community jurisprudence and doctrine. And the very motto of the EU [31] - "United in Diversity" - translates these ideals. Even the goal set out in 1995 by the European Union to bring citizens to be fluent in three foreign languages has not been fully achieved, although there are large differences between countries [18].

There is also the idea of extending citizenship with respect for fundamental rights which should be not confused [6], and that, nowadays, attentive to the aforementioned aspects, it goes beyond national citizenship and even European citizenship, since mobility is not limited to economic indicators and every human being that circulates creates bonds and that human mobility implies the exercise of fundamental rights where the right to education inscribes.

The subject on respect for the right to education is of the utmost relevance on the political agenda, and the European Parliament asked the European Commission to come forward a proposal on the drafting of a Union pact for democracy, the rule of law and fundamental rights. Furthermore, in the context of secondary law, that is, legislative or guiding documents resulting from the most general objectives within the institutive treaties, the concern regarding education is present. On this day, the main goal for education stems of the Europe 2020 strategy [16], as part of the EU's broader strategy for growth and jobs.

In a European global perspective, it is then reflected in quantifiable [14] (as determined in the Report on Portugal 2016 which includes a detailed assessment on the prevention and correction of macroeconomic imbalances, final document $\operatorname{SWD}(2016) 90)$ national objectives to guide employment- 
led investment as benchmarks of assessing progress [16]. This is followed by general incentives, which make it possible, for example, to direct teaching of all Member States to a high standard [12].

In a time when digital technologies, notably artificial intelligence and mobile technologies, allow democracy to be thought in a different way. So that we can see, European Union's treaties currently in force are in digital access ${ }^{1}$.

\section{THE PROMOTION OF TECHNOLOGIES BY THE EUROPEAN UNION IN THE CONTEXT OF EDUCATION}

The digital age, as mentioned, is transforming not only organizations but society in general. In the current context, IT is leading society in general to overcome "frontiers" in a way never anticipated, performing in the most diverse areas and for the most diverse purposes. As an example of this we can appoint the collection of signatures of the Instrument of European Citizenship Initiative through a computer platform, which allows the collection of online support statements, with the development of a computer programme and server utilization provided by the Commission to accommodate the data [10]; the adoption of the Single Digital Portal regulation which will enable citizens and businesses to find all the data, administrative procedures and assistant services related to their rights in the single market in a simple and easy accessible online portal ${ }^{2}$.

As mentioned, examples of the use of computer resources are in different fields. They have been foreseen by the civic movement that proposes to create a right to the continuous participation of all in the political life of the European Union and built a civic platform - www.civico.eu - and are already a reality in the citizens' consultations. Additionally to referred there are there are many others examples promoted by the EU, namely the use of the technologies on a recent survey relating the possibility of changing daylight saving time in Europe and the new priority given to artificial intelligence by the European Commission. These tools are referred repeatedly in the European Union's documentation as means of strengthening democratic values [23] and it is quite evident how they serve the purpose of building a stronger society towards integration through its use in all degrees of education [19]. The digitalization of European society, including in the education sector, may prove to be the most transformative effort in the EU at this time [13].

It is a gradual, multidimensional process that must be developed not only in classroom experience for students of all ages, but also in communication, assessment, management and administration, data collection and analysis, at all stages of education. This is not only a positive path, given these digital tools might have a limited scope [22], either for technical reasons or because by scarcity and inadequacy of skills in the EU to reform education and training systems [19].

Otherwise, the digital transformation which is the use of teaching instruments through digital means, is in line with the objectives of transparency pursued in European Union law, as set out in articles 15 (3) of the Treaty of the European Union in conjunction with Article 42 of the Charter of Fundamental Rights of the European Union in connection to law in the so-called "legislative footprint" of construction of the law [24].

\section{RELEVANCE OF DIGITAL TECHNOLOGIES IN THIS CONTEXT}

Information technologies (IT) are the essence of up-to-date organizations in general, and changes in this field are occurring at an uncontrollable pace, interrupting traditional models and forcing organizations to implement new models, new ways of working, communicating [7] and learn [33]. In this context, the EC, not ignoring the relevance and transformations inherent in the use of IT, where is included the internet with all its potential, namely information access, communication and work collaboration [3], has included its use in several areas.

As referred, digital technologies (Information Technologies (IT)) have become an integral part of human life in several areas, namely in education. Therefore, they must be included in all levels of education [32]. However, social inequality continues to influence the access pattern to these same technologies [27]. Those who are disadvantaged by non-access to IT experience a disappointment

\footnotetext{
${ }^{1}$ https://eur-lex.europa.eu/collection/eu-law/treaties/treaties-force.html

2 https://europa.eu/youreurope/index.htm
} 
feeling at seeing their carrying out daily activities compromised, namely as interaction, transaction and acquisition of information necessary for socioeconomic well-being in actual context [37].

Digital technologies are important tools in teaching learning process and other academic activities, hence the increasing use/implementation of technologies in educational institutions [38] but this implementation is far from global. According to Resta and Laferrière [36], is necessary occur a change in order to exist a digital equity to increase the opportunities for all stakeholders involved in education, particularly the students. Such equity thus contributes to improving the education of all students in a global society based on both knowledge and technology.

\section{CONCLUSIONS}

Education continues to be the means to privilege the maintenance of democratic values achieved by the rule of law. Digital media and technologies can assist educators in the use of new teaching and learning methods.

Without presenting quantitative data, the aim is to bring to discussion and debate the role value and capacity of the use of new technologies in enforcing a positive right that depends on the state's actions for its realization.

The analysis of the progress made historically towards the objectives of consolidating the right to education leads to the recommendation to the States, in their internal dimension and as members of international organizations, to value education as a vessel for the realization of democratic values. To this end, the role of new technologies will be preponderant if and to the extent that public policies value and promote them.

\section{REFERENCES}

[1] A. J. Fernandes, Direitos Humanos e Cidadania Europeia - Fundamentos e Dimensões. Coimbra: Almedina, 2004.

[2] A. Leitão, "Direito fundamental à educação, mercado público e contratação pública". e-Pública: Revista Eletrónica de Direito Público, I(2), pp. 115-129, 2014. Accessed 12 December, 2019. Retrieved from http://www.e-publica.pt/volumes/v1n2a05.html

[3] A. Murray, Information Technology Law: The Law and Society. Oxford: Oxford University Press, 2016.

[4] A. Silveira, and M. Canotilho, Direito da União Europeia: Elementos de direito e políticas da União. Coimbra: Almedina, 2016.

[5] A. Silveira, and M. Canotilho, Carta dos Direitos Fundamentais da União Europeia: Comentada. Coimbra: Almedina, 2013.

[6] A. Silveira, M. Canotilho, and P. M. Froufe, Direito da União Europeia. Coimbra: Almedina, 2016.

[7] B.-A. Schuelke-Leech, "A model for understanding the orders of magnitude of disruptive technologies". Technological Forecasting \& Social Change, V. 129, pp. 261-274, 2018.

[8] C. S. Botelho, Os direitos sociais em tempos de crise. Coimbra: Almedina, 2017.

[9] Council of Europe, Charter on Education for Democratic Citizenship and Human Rights Education. http://www.coe.int/edc , 2010.

[10] European Commission, Report to the European Parliament and the Council on the application of Regulation (EU) No 211/2011 on the citizens' initiative. Document COM (2018) 157 on 28.03.2018.

[11] European Commission, Communication to the European Parliament, the Council, the European Economic and Social Committee and the Committee of the Regions. Strengthening European Identity through Education and Culture the European Commission's contribution to the Leaders' meeting in Gothenburg, 17 November 2017. Document COM (2017) 673 on 14.11.2017.

[12] European Commission, Communication to the European Parliament, the Council, the European Economic and Social Committee and the Committee of the Regions Improving and modernising education. Document COM (2016) 941, on 07.12.2016. 
[13] European Commission, Education and Training Monitor. Directorate-General of Education and Culture (DG EAC), November of 2016. Available: https://ec.europa.eu/education/ sites/ education/ files/monitor2016_en.pdf

[14] European Commission, Document SWD (2016) 90 final, on 26.2.2016.

[15] European Commission, Communication to the European Parliament, the Council, the European and Social Committee and the Committee of the Regions Supporting growth and jobs - an agenda for the modernization of Europe's higher education systems. Document COM (2011) 567, on 20.09.2011.

[16] European Commission, Europe 2020: A strategy for smart, sustainable and inclusive growth. Document COM (2010) 2020, on 03.03.2010.

[17] European Commission, Communication to the Council and the European Parliament Delivering on the modernisation agenda for universities: education, research and innovation. Document COM (2006) 208, on 10.05.2006.

[18] European Commission, White Paper on Education and Training - Teaching and Learning Towards the Learning Society. Document COM (95) 590, on 29.11.1995.

[19] European Committee of the Regions, Opinion 2018/C 361/05 - Strengthening European Identity through Education and Culture, OJEU C 561, on 05.10.2018, pp. 19-30.

[20] European Council, Conclusions 2017/C 62/02 of the Representatives of the Governments of the Member States, meeting within the Council, on Inclusion in Diversity to achieve a High Quality Education For All. OJEU C 62, on 25.02.2017, pp. 3-7.

[21] European Council, Proclamation 2000/C 364/01 of the Charter of Fundamental Rights, OJEC C 364, 18.12.2000.

[22] European Parliament, Resolution 2018/C 346/29 of 26 October 2017 on monitoring the application of EU law 2015, OJEU C 337, on 20.09.2018, pp. 226-233.

[23] European Parliament, Resolution 2018/C 337/04 of 12 September 2017 on academic further and distance education as part of the European lifelong learning strategy, OJEU C 337 de 20.09.2018, 20-29.

[24] European Parliament, Resolution 2018/C 337/18 of 14 September 2017 on transparency, accountability and integrity in the EU institutions, OJEU C 337 de 20.09.2018, pp. 120-130.

[25] European Parliament, Resolution 2016/C 346/21 of 28 April 2015 on follow-up on the implementation of the Bologna Process (2015/2039(INI)), OJEU C 346 on 21.09.2016.

[26] European Parliament, Consolidated version 2016/C 202/01 Charter of Fundamental Rights of the European Union, OJEC C 202 of 07.06.2006.

[27] F. Moreira, M. J. Ferreira, and I. Seruca, "Enterprise 4.0 - the emerging digital transformed enterprise?" Procedia Computer Science, 138, pp. 525-53, 2018. https://doi.org/10.1016/ j.procs.2018.10.072

[28] J. J. Gomes Canotilho, and V. Moreira, Constituição da República Portuguesa anotada. Coimbra: Coimbra Editora, 2007.

[29] J. K. Gillett-Swan, and J. Sargeant, "Voice Inclusive Practice, Digital Literacy and Children's Participatory Rights". Children \& Society, 32(1), pp. 38-49, 2018. https://doi.org/ 10.1111/ chso. 12230

[30] J. Miranda, As Constituições Portuguesas de 1822 ao texto actual da Constituição. (3rd Ed.). Lisboa: Petrony, 1992.

[31] J. Swiebel, "Intercultural dialogue and diversity within the EU". Seminar on European Parliament to Campus for Intercultural Dialogue and the European Neighbourhood Policy in the Carpathian Area, 4-11 June, pp. 101-112, 2008.

[32] M. J. Ferreira, F. Moreira, and I. Seruca, "Digital Transformation Towards a New Context of Labour", Technological Developments in Industry 4.0 for Business Applications Advances in Logistics, Operations, and Management Science, pp. 26-49, 2019. doi:10.4018/978-1-5225-49369.ch002 
[33] M. J. Ferreira, F. Moreira, and I. Seruca, "Organizational Training within Digital Transformation: The ToOW Model". Proceedings of the 19th International Conference on Enterprise Information Systems, 2, pp. 526-532, 2017. doi: 10.5220/0006366105260532

[34] M. L. Porto, and G. Anastácio (coord.), Tratado de Lisboa - anotado e comentado. Coimbra: Almedina, 2012.

[35] M. M. M. Silva, and D. R. Alves, Noções de Direito Constitucional e Ciência Política. (3rd. Ed.) Lisboa: Rei dos Livros, 2016.

[36] P. Resta, and T. Laferrière, "Digital equity and intercultural education", Education and Information Technologies, 20(4), pp.743-756, 2015. doi: 10.1007/s10639-015-9419-z

[37] T. D. Oyedemi, "Digital inequalities and implications for social inequalities: A study of Internet penetration amongst university students in South Africa". Telematics and Informatics, 29, pp. 302313, 2012. https://doi.org/10.1016/j.tele.2011.12.001

[38] T. Oyedemi, and S. Mogano, "The Digitally Disadvantaged: Access to Digital Communication Technologies among First Year Students at a Rural South African University", Africa Education Review, 15:1, pp. 175-191, 2018. doi: 10.1080/18146627.2016.1264866 